Механізм збалансування інтересів учасників транспортного ринку призначений для перетворення потенційного або незадоволеного попиту та потенційної пропозиції у реальний попит та пропозицію перевезення $i$-того роду вантажу. Тобто, досягається відповідність між пропозицією перевізника та потребою споживача транспортних послуг при певному рівні тарифу на перевезення $i$ того роду вантажу.

Висновок. Резюмуючи викладене, слід наголосити, про обгрунтованість маркетингового підходу до ціноутворення на вантажні залізничні перевезення, що враховує потреби споживачів, у частині оптимального рівня тарифів (в тому числі надання знижок у разі укладання довгострокових договорів), що забезпечить залучення додаткових обсягів перевезень вантажів, та потреби перевізника, а саме забезпечення покриття витрат на перевезення та збільшення доходів. Перспективою подальших досліджень $\epsilon$ визначення зміни обсягів перевезень та доходів залежно від варіації тарифу на перевезення $i$-того роду вантажу 3 урахуванням еластичності попиту.

\section{СПИСОК ЛІТЕРАТУРИ}

1. Богомолова Н. І. Ціноутворення в умовах доставки вантажів i пасажирів на залізничному транспорті / Н.І. Богомолова // Електронне фахове видання «Ефективна економіка». - 2010. - № 1 [Електронний ресурс]. - Режим доступа: http://www.economy.nayka.com.ua/?op=1\&z=105

2. Колесникова Н.М. Формування ефективного попиту як важлива функція ціноутворення по вантажних залізничних перевезеннях / Колесникова Н.М., Чорний В.В. // Збірник наукових праць ДЕТУТ. Серія «Економіка і управління», 2010. Вип. 15. - С. 44 - 49.

3. Колесникова Н.М. Адаптивногармонізаційний механізм ціноутворення на залізничному транспорті: формування, функціонування та розвиток: [монографія] / Н.М. Колесникова. - К.: КУЕТТ, 2006. - 564 с.

4. Макаренко М. В. Основи управління економічними процесами на залізничному транспорті України: [монографія] / М.В. Макаренко. - K.: KУЕTТ, 2003. - 478 c.

5.Чебанова Н.В. Теоретические подходы к совершенствованию системы ценообразования на основе учета спроса на грузовые перевозки / Н.В. Чебанова, Л.Е. Ревуцкая // Коммунальное хозяйство городов: Науч.-техн. сб. Серия: экономические науки. - 2001. - Вып. 34. - С. 170-177.

6. Чорний В.В. Конкурентоспроможність залізниць на ринку вантажних перевезень: теорія, методологія, практика: [монографія] / В.В. Чорний. - К.: ДЕТУТ, 2012. - 401 c.

\title{
ЗАБЕЗПЕЧЕННЯ ЕКОНОМІЧНОЇ БЕЗПЕКИ ЗАЛІЗНИЧНОГО ТРАНСПОРТУ 3 УРАХУВАННЯМ ВИКОРИСТАННЯ ІНФОРМАЦІЙНИХ СИСТЕМ
}

Тимофсква Т.О., к.е.н., доцент, (УкрДАЗТ)

Сформовано комплексний підхід до формування механізму забезпечення економічної безпеки залізничного транспорту. Виявлено вплив рівня інформачійної складової на рівень забезпечення економічної безпеки залізничного транспорту. Встановлено, шзо система економічної безпеки залізничного транспорту повинна формуватися з використанням сучасних інформаційних систем. Виявлено загрози, які дають можливість визначити чинники, щьо негативно впливають на рівень інформачійної складової економічної безпеки залізничного транспорту.

Ключеві слова: механізм забезпечення, економічна безпека залізничного транспорту, інформаційне середовище, принципи управління, методика побудування. 


\title{
ОБЕСПЕЧЕНИЕ ЭКОНОМИЧЕСКОЙ БЕЗОПАСНОСТИ ЖЕЛЕЗНОДОРОЖНОГО ТРАНСПОРТА С УЧЕТОМ ИСПОЛЬЗОАНИЯ ИНФОРМАЦИОННЫХ СИСТЕМ
}

\author{
Тимофеева Т.Е, к.е.н., доцент, (УкрГАЖТ)
}

\begin{abstract}
Определен комплексный подход к формированию механизма обеспечения экономической безопасности железнодорожного транспорта. Определено влияние уровня информационной составляющей на уровень обеспечения экономической безопасности железнодорожного транспорта. Установлено, что система экономической безопасности железнодорожного транспорта должна формироваться с использованием современных информационных систем. Определены угрозы, которые дают возможность определить факторы негативно влияющие на уровень информационной составляющей экономической безопасности железнодорожной отрасли.
\end{abstract}

Ключеві слова: механизм обеспечения, экономическая безопасность жселезнодорожного транспорта, информационная среда, принципы управления, методика построения.

\section{ENSURING THE ECONOMIC SAFETY OF RAILWAY TRANSPORT INTO ACCOUNT THE MODERN INFORMATIVE SYSTEMS}

\author{
Timofeeva T.E. Candidate of Economic Sciences, associate professor (USA of RT)
}

The development of market relations in Ukraine causing general changes in social life, resultingg come up a problem of ensuring economic safety of railway transport, which is in such condition, in which are creating conditions for most effective using branch's resources and ensuring stable functioning and progressive development in our and time and in future. Creating such condition from process of adopting necessary in these requisitions and these period of time informed managment dicision.

A complex approach is formulated to the forming a mechanism of the providing an economic safety of railway transport. Discovered an influance from information part level on level of ensuring economic safety of railway transport. It is set, that the system of economic safety railway transport must be built taking into account the modern informative systems. Discovered danger, which gives an opportunity to detect factors, which have negative influance on information part of ensuring economic safety of railway transport.

Keywords: mechanism of the providing, economic safety of railway transport, informative environment, management principles, construction method.

Постановка проблеми. Залізничний транспорт є складовою частиною господарського комплексу країни, який забезпечує необхідні потреби в реалізації економічних і соціальних зв'язків між різними галузями і регіонами країни, а також за іiі межами. I саме тому рівень розвитку залізничного транспорту повинен відповідати, а у ряді випадків навіть випереджати рівень розвитку основних галузей народного господарства України. У зв'язку зі змінами у суспільному житті країни, внаслідок чого виникає проблема забезпечення економічної безпеки залізничного транспорту, яка полягає в формуванні такого його стану, при якому створюються умови для найефективнішого використання ресурсів галузі i забезпечення стабільного функціонування i прогресивного розвитку в даний час і в майбутньому. Створення такого стану залежить від процесу ухвалення необхідного в даних умовах і в даний період часу обгрунтованого управлінського рішення.

Аналіз останніх досліджень та
публікацій. Дослідженню проблем економічної безпеки підприємств приділили увагу такі вченіекономісти, як Васильцев Т.Г. [1], Довбня С.Б. [2], Кавун С.В. [3], Кириченко О.А. [4], Геєць В.М. [5], Кизим М.О. [5], Клебанова Т.С. [5], Черняк О.І. [5], Судакова O.I. [7], Шкарлет С.М. [8] та інші. В своїх працях автори описують проблематику управління економічною безпекою підприємства, як в цілому, так i по окремим складовим елементам. Значна увага приділяється визначенню сутності економічної безпеки, іiі елементів, необхідності всестороннього дослідження цього явища, а також розглядаються підходи до ії̈ оцінки.

Виділення невирішених проблем. В даний час процес ухвалення будь-якого управлінського рішення відбувається в умовах невизначеності результатів, обмеженої, недостатньо повної і вірної інформації, наявності зацікавленості конкурентів в вилученні інформації з подальшим використанням iii в своїх цілях. Тому вплив рівня інформаційної складової на рівень економічної безпеки залізничного транспорту дуже великий. 
Mетою cmammi є виявлення впливу рівня інформаційної складової на рівень забезпечення економічної безпеки залізничного транспорту.

\section{Виклад основного матеріалу}

дослідження. Актуальність проблеми створення системи забезпечення необхідного рівня інформаційної складової економічної безпеки залізничної галузі підтверджує той факт, що 3 одного боку, використання надійної інформації впливає на правильність управлінських рішень, що приймаються, а це призводить до мінімуму ризик фінансових, виробничих та будь-яких витрат, що в свою чергу підвищує рівень інших складових економічної безпеки залізничного транспорту. 3 іншого боку, сама по собі інформація, пов'язана 3 діяльністю залізничного транспорту виступає об'єктом захисту, оскільки володіння певною частиною інформації про діяльність залізничного транспорту для конкурентів створює сприятливі умови для її використання.

Ефективність функціонування будь-якої системи залежить від ступеня іiі інформованості про стан своїх підсистем, а також про процеси зміни, які в них відбуваються. Наявність системи, за допомогою якої буде забезпечено отримання інформації 3 будь-якого питання, що цікавить, забезпечує можливість ефективно планувати експлуатаційну роботу галузі.

Тому сутність інформаційної складової економічної безпеки полягає в такому стані, при якому можливе отримання своєчасної і достовірної інформації інформаційно-аналітичними службами для проведення подальшого аналізу одержаної інформації, захист інформації від несанкціонованого доступу і вживання необхідних заходів для забезпечення економічної безпеки.

Повноправність інформаційної складової серед інших складових залізничного транспорту підтверджують дослідники Мішечкін В.Г., Юрченко О.В., які стверджують, що подальший розвиток залізничного транспорту неможливий без модернізації центральних комплексів інформаційних статистичних центрів дороги за допомогою впровадження ліцензійного програмного забезпечення, а також підключення ізольованих баз даних до багатофункціональних баз [6].

На рівень інформаційної складової економічної безпеки залізничного транспорту впливає ряд чинників як внутрішніх, так зовнішніх, як позитивних, так i негативних. В даному випадку нас більше цікавлять негативні чинники, тобто загрози. Загрози - це дії, які прямо або побічно направлені на зменшення рівня стабільності інформаційної складової. Загрози, у свою чергу можна розділити на внутрішні i зовнішні. Під внутрішніми загрозами ми розумітимемо загрози, що включають помилки і неякісні дії співробітників галузі, під зовнішніми загрози, не пов'язані з діяльністю самої галузі, але що безпосередньо негативно впливають на iï діяльність.

До зовнішніх загроз інформаційної складової економічної безпеки відноситься підрив репутації залізничного транспорту за допомогою надання спотвореної інформації про якість надання послуг, фінансові махінації.

Виникнення мережних комунікацій, що мають на сьогоднішній день глобальний характер, несе в собі і безліч небезпек, пов'язаних 3 існуванням електронних вірусів, які здатні вивести 3 ладу будь-яку інформаційну систему за дуже невеликий період часу i завдати великого матеріального збитку.

Як показав моніторинг інформаційних компаній США і Росії, в половині цих компаній відсутні системи виявлення вторгнень у внутрішні мережі [8]. Крім цього, ще і не всі компанії використовують антивірусні програми. Своєю бездіяльністю, або старанням заощадити засоби, вони піддають себе безлічі несподіванок, до яких можна віднести і промислове шпигунство, і вихід 3 ладу всієї мережної комунікації.

Крім того комунікаційна система залізничного транспорту є формальним каналом 3 якого конкуренти можуть отримати необхідну для них інформацію для подальшого її використання в своїх цілях. До такої інформації можна віднести відомості про всі ресурси залізничного транспорту, а також можливі структурні та інші зміни в його діяльності.

Окрім формального каналу втрати інформації про стан залізничного транспорту в різних аспектах його діяльності $\epsilon$ ще й неформальні канали, де головну роль має людський фактор. Втрата інформації може виникнути під час спілкування "носіїв" важливої інформації за межами підприємств.

Ще одним каналом втрати інформації можуть бути об'єкти зовнішнього середовища 3 якими підприємства залізничного транспорту підтримують різного роду зв'язки. До них можна віднести постачальників ресурсів, споживачів продукції, податкові та екологічні інспекції, банки, страхові компанії, учбові заклади, статистичні органи, органи державної влади та місцевого самоуправління. 


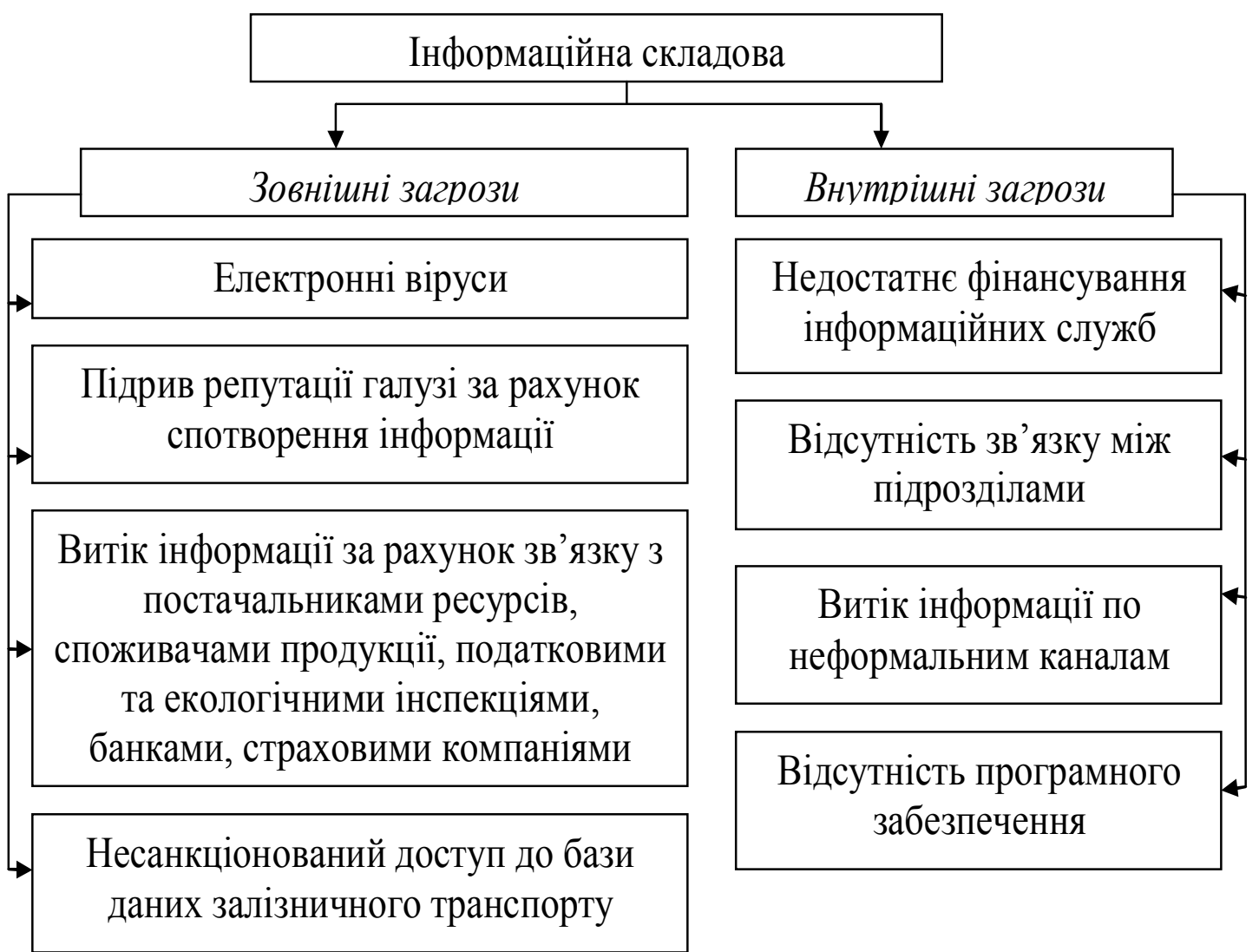

Рис. 1 Види загроз інформаиійної складової економічної безпеки залізничного транспорту

Для вилучення необхідної інформації використовуються як легальні (використання експертів), напівлегальні (бесіди зі спеціалістами, неправдиві конкурси та найми, запрошення консультантів, переманювання спеціалістів, використання жіночої краси), так і нелегальні методи (викрадення або копіювання документів, підслуховування, проникнення в комп'ютерну мережу, викрадення власності).

Джерела можливого витоку інформації про діяльність залізничного транспорту представлено на рисунку 2.

Внутрішніми загрозами $є$ недостатнє забезпечення інформаційних служб спеціальними технічними засобами для збору, обробки, класифікації і складання бази даних одержаної інформації, а також незатребуваність, нерозуміння, невміння використовувати інформацію, за допомогою якої можна здійснювати комплексне прогнозування i розробку найоптимальнішої стратегії управління виробництвом.

Виявлені загрози дають можливість визначити чинники, що негативно впливають на рівень інформаційної складової економічної безпеки залізничного транспорту та оцінити їх вплив на економічну безпеку галузі 3 метою розробки оптимальних методів усунення загроз.

Висновок. Таким чином, в сьогоднішніх умовах залізнична галузь потребує створення потужної системи забезпечення необхідного рівня інформаційної складової економічної безпеки. 




Рис. 2 Джерела втрати інформації про діяльність залізничного транспорту 


\section{СПИСОК ЛІТЕРАТУРИ}

1. Васильцев Т.Г. Экономическая безопасность предпринимательства в Украине: стратегия и механизмы укрепления: моногр. / Т.Г. Васильцев; Национальный институт стратегических исследований. - Львов, 2008. - 385 c.

2. Довбня С.Б. Диагностика уровня экономической безопасности предприятия / С.Б. Довбня, Н.Ю. Гичова // Финансы Украины. - 2013. - 4. - C.91-97.

3. Кавун С.В. Концептуальная модель системы экономической безопасности предприятия / С.В. Кавун // Научный журнал «Экономика развития». - Х.: ХНЕУ. - 2013. - №3 (43). - С. 97101.

4. Кириченко О.А. Некоторые критерии оценки экономической безопасности предприятия / О.А. Кириченко // Инвестиции: практика и опыт. 2012. - № 23. - C.22-24.
5. Моделирование экономической безопасности: государство, регион, підприємство: Моногр./ В.М.Геець, М.О.Кизим, Т.С.Клебанова, О.И Черняк. и др.; Под ред. Гейца В.М.: - Х.: ВД «ИНЖЕК», 2006. - 240 с.

6. Мішечкін В.Г. Підвищення якості інформаційного забезпечення управління транспортом. / В.Г. Мішечкін, О.В Юрченко та ін. // Залізничний транспорт України. - 2002. - №6. C.2-3.

7. Судаковая О.И. Формирование системы управления экономической безопасностью предпринимательства / О. И. Судаковая // Экономика: проблемы теории и практики: сб. науч. трудов. - Днепропетровск: ДНУ, 2012. - Т. 8. - С. 165-171.

8. Шкарлет С.М. Формирование экономической безопасности предприятий средствами активизации их инновационного развития: Автореф. / С.М. Шкарлет - К.: Либра, 2008.- 24 c.

\title{
УДК 331.107.5:656.2
}

\section{ПЕРЕВАГИ РЕАЛІЗАЦІЇ СТРАТЕГІЧНОГО БІЗНЕС-ПАРТНЕРСТВА НА ЗАЛІЗНИЧНОМУ ТРАНСПОРТІ}

\author{
Токмакова І.В., к.е.н., доцент (УкрДАЗТ)
}

В статті проводиться аналіз мотиваційних чинників впровадження стратегічного бізнеспартнерства, розкрито напрямки реалізації стратегічного партнерства за участю підприємств залізничного транспорту, визначено особливості переваг стратегічного бізнес-партнерства як чинника конкурентоспроможності в сучасних умовах господарювання, запропоновано поняття «емерджентні переваги стратегічного бізнес-партнерства» та обгрунтовано його зміст з урахуванням ключового значення розвитку колективних компетенцій для забезпечення успішної діяльності залізничного транспорту.

Ключові слова: стратегічне бізнес-партнерство, компетенція, емерджентна перевага, синергетичний ефект, залізничний транспорт.

\section{ПРЕИМУЩЕСТВА РЕАЛИЗАЦИИ СТРАТЕГИЧЕСКОГО БИЗНЕС- ПАРТНЕРСТВА НА ЖЕЛЕЗНОДОРОЖНОМ ТРАНСПОРТЕ}

\author{
Токмакова И.В., к.э.н., доцент (УкрГАЖТ)
}

В статье проводится анализ мотивационных факторов внедрения стратегического бизнеспартнерства, раскрыты направления реализации стратегического партнерства с участием предприятий железнодорожного транспорта, определены особенности преимуществ стратегического партнерства как фактора конкурентоспособности в современных условиях хозяйствования, предложено понятие «эмерджентные преимущества стратегического бизнес-партнерства» $u$ обосновано его содержание с учетом ключевого значения развития коллективных компетенций для обеспечения успешной деятельности железнодорожного транспорта. 